Int. J. Electrochem. Sci., 12 (2017) $5012-5022$

\title{
Application of Graphene and Pyridine in Anode Modification for Enhanced Performance of Microbial Fuel Cells
}

\author{
Kun Cao \\ Department of Chemistry \& Chemical Engineering, Neijiang Normal University, Neijiang, Sichuan, \\ 641112, PR China \\ E-mail: kevin_cao0811@126.com
}

doi: $10.20964 / 2017.06 .64$

Received: 28 June 2016 / Accepted: 23 March 2017 / Published: 12 May 2017

Carbon cloth was modified by graphene oxide, and then electropolymerized 2,6-Pyridinedicarboxylic acid (PDC) on the treated carbon cloth, which was as anode for microbial fuel cells. The power density of the modified carbon cloth reaches $1035 \mathrm{~mW} \cdot \mathrm{m}^{-2}$, which was 3.2 times larger than that of the MFCs with the unmodified carbon cloth anode. BET, scanning electron microscopy (SEM) and Raman spectroscopy were employed to detect the surface characteristics of the carbon cloth. CV and electrochemical impedance spectroscopy (EIS) were used to confirm the electrochemical characteristics. The results showed that graphene oxide and PDC could improve the charge transfer performance and bacterial reproduction.

Keywords: Microbial fuel cells, electropolymerized, Electrochemically reducing graphene oxide, Pyridinedicarboxylic

\section{$\underline{\text { FULL TEXT }}$}

(C) 2017 The Authors. Published by ESG (www.electrochemsci.org). This article is an open access article distributed under the terms and conditions of the Creative Commons Attribution license (http://creativecommons.org/licenses/by/4.0/). 